\title{
Shear Strength of Normal and Light Weight Reinforced Concrete Slender Beams without Web Reinforcement
}

\author{
Shuaib H. Ahmad, Shamsoon Fareed", S.F.A.Rafeeqi \\ NED University of Engineering \& Technology, Karachi-Pakistan \\ *Corresponding Author: sfareed@neduet.edu.pk
}

Copyright (C) 2014 Horizon Research Publishing All rights reserved.

\begin{abstract}
There is no general consensus or accepted theory for evaluating the ultimate shear capacity of reinforced concrete beams without web reinforcement as a result the requirements in most of Codes of practice are provided in the form of empirical equations for predicting the shear capacity of reinforced concrete beams. In this paper, a study is conducted to evaluate the predictive accuracy of 6 empirical equations used in different Code of practice to predict the shear capacity of reinforced concrete slender beams. Empirical equations used in some Codes are identified to be superior to other equations. In addition, a study was also conducted to assess predictive accuracy of 17 empirical equations proposed in the literature by several researchers to predict the shear capacity of reinforced concrete slender beams. Among these 17 empirical equations some equations are identified to be superior to the other proposed equations. On the basis of experimental results of reinforced concrete beams having shear span to depth ratio $\mathrm{a} / \mathrm{d} \geq 2.5$, empirical equations are proposed which include basic parameters i.e. concrete compressive strength shear span to depth ratio and ratio of longitudinal reinforcement. The coefficient of correlation (COR) for proposed empirical equation for predicting the shear capacity of reinforced concrete beams having depth $\mathrm{d}<300 \mathrm{~mm}$ and $\mathrm{d} \geq 300 \mathrm{~mm}$ without web reinforcement comes out to be 0.869 and 0.953 respectively.
\end{abstract}

Keywords Empirical Equations, Shear Strength, Slender Beams, Concrete Compressive Strength

\section{Introduction}

Extensive research over the years on the combined effects of flexure and shear on the resistance capacity of the structure has not yielded a generalized theory of combined flexure shear for computing the resistance capacity of reinforced concrete members [1], [2]. As a result, the design for shear is uncoupled with respect to the flexural design.

Most of the code of practices uses empirical equations to estimate the shear capacity of reinforced concrete beams. In addition to the equations in the Codes, there are number of empirical equations proposed in the literature by different researchers. Empirical equations developed from experimental results for calculating $\mathrm{Vc}$ involves different influencing parameters based on the variable considered in the experimental program by the researcher. Each researcher has selected different influencing parameters as there is no general consensus or accepted theory for evaluating the ultimate shear capacity of reinforced concrete beams without web reinforcement.

In this paper, Design equations used in six (6) Design Codes of practice were evaluated using the experimental data contained in ACCESS shear database [3].Predictive accuracy of 17 empirical equations proposed in the literature for predicting the shear capacity of reinforced concrete slender beams a/d $>2.5$, were studied using the experimental data contained in ACCESS shear database [3]. On the basis of results, for slender reinforced concrete beams, empirical equations used in some Codes are identified to be superior to others. Among the proposed empirical equations in the literature, equations that use the use $\left(f^{\prime} \mathrm{c}\right)^{1 / 3}$ function and include depth factor are found to be superior to others.

On the basis of experimental results of reinforced concrete beams [3] having shear span to depth ratio $\mathrm{a} / \mathrm{d} \geq 2.5$, empirical equations are proposed which include basic parameters i.e. concrete compressive strength $f^{\prime} \mathrm{c}$, shear span to depth ratio a/d and ratio of longitudinal reinforcement $\rho$. The coefficient of correlation (COR) for proposed empirical equation for predicting the shear capacity of reinforced concrete beams having depth $\mathrm{d}<300 \mathrm{~mm}$ and $\mathrm{d} \geq 300 \mathrm{~mm}$ without web reinforcement comes out to be 0.869 and 0.953 respectively.

\section{Evaluation of Design Equations}

Equations 1 to 6 shows empirical equations in different Codes of practice along with their limits of applicability used to predict the shear capacity of reinforced concrete slender beams. For the study of predictive accuracy of the Code equations, experimental data for slender beams from the shear database [3] was used.

It can be seen that to reflect the effect of concrete compressive strength $f^{\prime} \mathrm{c}$ on the shear capacity of reinforced 
concrete beams, ACI Code [4] Eq. 1, Canadian Code [5] Eq. 2 and New Zealand Code [6] Eq. 3 use function $\left(f^{\prime} c\right)^{1 / 2}$, whereas the Euro code EC2 [7] Eq.4 , Espanish Code EHE-99 [8] Eq. 5 and CEB-FIP Model Code [9] Eq.6 use function $\left(f^{\prime} c\right)^{1 / 3}$. The influence of size effect on the shear capacity is not included in the equations of ACI Code [4] Eq. 1, and New Zealand Code [6] Eq. 3, whereas the equations of the other Codes have terms that accommodate the influence of size effect.

$$
\begin{gathered}
\vartheta_{c r}=0.16 \sqrt{f^{\prime}{ }_{c}}+17.2 \rho \frac{V d}{M} \quad \text { for } \mathrm{a} / \mathrm{d} \geq 2.5 \\
\vartheta_{c r}=0.2 \sqrt{f^{\prime}{ }_{c}} \quad \text { for } \mathrm{d} \leq 300 \mathrm{~mm} \\
\vartheta_{c r}=\left(\frac{260}{1000+d}\right) \sqrt{{f^{\prime}}_{c} \geq 0.1 \sqrt{f^{\prime}{ }_{c}} \quad \text { for } \mathrm{d}>300 \mathrm{~mm}} \\
\vartheta_{c r}=(0.07+10 \rho) \sqrt{f^{\prime}{ }_{c}} \quad \text { for } \mathrm{a} / \mathrm{d}>2.0 \\
\vartheta_{c}=\frac{0.18}{\gamma_{c}} K\left(100 \rho_{l} f_{c k}\right)^{1 / 3}+0.15 \sigma_{c p} \\
\vartheta_{c} \min =0.035 k^{3 / 2} f_{c k}{ }^{1 / 2}
\end{gathered}
$$

where

$$
f_{c k} \leq 100 \mathrm{MPa}
$$

$$
k=1+\sqrt{\frac{200}{d}} \leq 2
$$

where $\mathrm{d}$ is in $\mathrm{mm}$

$$
\begin{array}{r}
\rho_{l}=\frac{A_{s}}{b_{w} d} \leq 0.02 \\
\vartheta_{c}=0.12 \xi\left(\rho_{s} f_{c k}\right)^{1 / 3}-0.15 \sigma_{c d}
\end{array}
$$

where

$$
\begin{gathered}
\xi=1+\sqrt{\frac{200}{d}} \\
\vartheta_{c}=0.12\left(1+\sqrt{\frac{200}{d}}\right)\left(\frac{3 d}{a_{s}}\right)^{1 / 3}\left(\rho_{s} f_{c k}\right)^{1 / 3}-0.15 \sigma_{c d}
\end{gathered}
$$

where

$$
\mathrm{N}_{\mathrm{d}}=\text { Factored Axial Force }
$$$$
\mathrm{Ac}=\text { Area of concrete }
$$

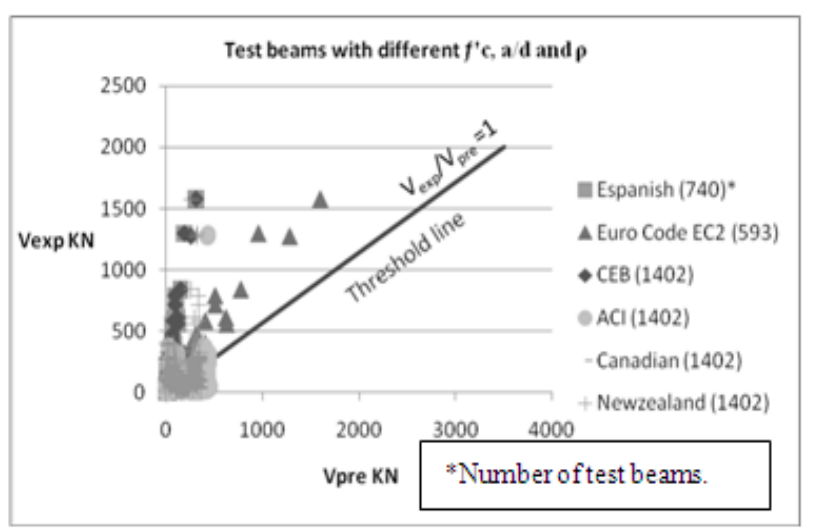

Figure1. Comparison of prediction of Code equations with experimental results.
Fig. 1 shows the plot of the experimental (measured) ultimate shear force $\left(\mathrm{V}_{\text {exp }}\right)$ and predicted ultimate shear force $\left(\mathrm{V}_{\text {pre }}\right)$, for all the 6 code equations, along with the threshold line $\left(\mathrm{V}_{\text {exp }} / \mathrm{V}_{\text {pre }}=1\right)$. It can be seen from Fig. 1 , the $\left(\mathrm{V}_{\text {exp }} / \mathrm{V}_{\text {pre }}\right)$ of CEB-FIP Model Code [9] Eq. 6 and Espanish EHE-99 Code [8] Eq. 5 are much greater than 1, which shows that these two codes significantly underestimate the shear capacity of reinforced concrete slender beams, as compared to ACI Code [4] Eq. 1, Euro Code EC2 [7] Eq. 4, New Zealand Code [6] Eq. 3 and Canadian Code [5] Eq. 2.

Table 1. Summary of results for the Average Margin of Safety $\left(\mathrm{V}_{\text {exp }} / \mathrm{V}_{\text {pre }}\right)_{\text {avg }}$ of empirical equations used in different Codes for predicting the shear capacity of normal strength and high strength reinforced concrete slender beams.

\begin{tabular}{|c|c|c|}
\hline Code & $\begin{array}{c}\text { No. of Beams } \\
\text { used for } \\
\text { Evaluation }\end{array}$ & $\begin{array}{c}\text { *Average Margin of } \\
\text { Safety } \\
\text { (Vexp/Vpre)avg }\end{array}$ \\
\hline CEB-FIP Model & 1402 & 7.214 \\
\hline Espanish EHE-99 & 740 & 6.539 \\
\hline ACI & 1402 & 1.314 \\
\hline Eurocode EC2 & 593 & 1.273 \\
\hline NewZealand Code & 1402 & 1.207 \\
\hline Canadian Code & 1402 & 1.209 \\
\hline
\end{tabular}

Table 1 shows the summary of results in terms of the comparison of the average Margin of Safety $\left(\mathrm{V}_{\text {exp }} / \mathrm{V}_{\text {pre }}\right)_{\text {avg }}$ of design equations used in different Codes of practice for predicting the shear capacity of reinforced concrete slender beams. The number of beams, whose data was used, varies for each case, because of the relative constraints or the limits in the respective empirical equations of the Codes. From Table 1 it can be seen that the average Margin of Safety $\left(\mathrm{V}_{\text {exp }} / \mathrm{V}_{\text {pre }}\right)_{\text {avg }}$ for CEB-FIP Model Code [9]Eq. 6 and Espanish EHE-99 Code [8] Eq. 5 is 7.214 and 6.539 respectively which is much higher than $\left(\mathrm{V}_{\mathrm{exp}} / \mathrm{V}_{\mathrm{pre}}\right)_{\text {avg }}$ values, when using the ACI Code [4] Eq. 1, Euro Code EC2 [7] Eq. 4, New Zealand Code [6] Eq. 3 and Canadian Code [5] Eq. 2.which are $1.325,1.273,1.207$ and 1.209 respectively. Thus the CEB-FIP Model Code [9] Eq. 6 and Espanish EHE-99 Code [8] Eq. 5 estimations are significantly more conservative (order of 6 or higher) as compared to other codes and are not considered in the further evaluation.

\subsection{Effect of Influencing Factors}

Two major factors are studied, the concrete compressive strength and the size effect. Table 2 shows the summary of results showing the Average Margin of Safety $\left(\mathrm{V}_{\text {exp }} / \mathrm{V}_{\text {pre }}\right)_{\text {avg }}$ with coefficient of correlation (COR) for Normal Strength Concrete (NSC) having $f^{\prime} \mathrm{c}<40 \mathrm{MPa}$ and High Strength Concrete (HSC) having $f^{\prime} \mathrm{c} \geq 40 \mathrm{MPa}$ reinforced slender beams. It can be seen from Table 2 that in case of NSC beams, COR for Euro code EC2 Code [7] Eq. 4 is 0.974, which is higher as compared to New Zealand Code [6] Eq. 3 , Canadian Code [5] Eq. 2 and ACI Code [4] Eq. 1, which are 
$0.855,0.932$ and 0.899 respectively.

In case of HSC beams, COR for Euro code EC2 [7] Eq. 4 is 0.974 which is higher as compared to New Zealand Code [6] Eq. 3 , Canadian Code [5] Eq. 2 and ACI Code [4] Eq. 1 which are $0.882,0.932$ and 0.90 respectively. It should be noted that Euro code EC2 [7] Eq. 4 equation uses cubic root function $\left(f^{\prime} \mathrm{c}\right) 1 / 3$ rather than the square root function $\left(f^{\prime} \mathrm{c}\right){ }^{1 / 2}$ used by ACI Code [4] Eq. 1, Canadian Code [5] Eq. 2 and Newzealand Code [6] Eq. 3 to reflect the effect of the concrete compressive strength $f^{\prime} \mathrm{c}$ on the shear capacity of reinforced concrete beams. This implies that $\left(f^{\prime} \mathrm{c}\right)^{1 / 2}$ function used in the ACI Code [4] Eq. 1, Canadian Code [5] Eq. 2 and Newzealand Code [6] may not be adequate to reflect the effect of the $f^{\prime} c$ on the shear capacity of high strength reinforced concrete beams.

Table 2. Summary of results showing the Average Margin of Safety with coefficient of correlation for NSC and HSC reinforced slender beams.

\begin{tabular}{|c|c|c|c|c|}
\hline \multirow{3}{*}{ Code } & \multicolumn{4}{|c|}{ Strength of Concrete } \\
\hline & \multirow{2}{*}{$\begin{array}{c}\text { No. of } \\
\text { Beams } \\
\text { used for } \\
\text { evaluation }\end{array}$} & $\mathrm{NSC}$ & \multirow{2}{*}{$\begin{array}{c}\text { Average } \\
\text { Margin of } \\
\text { Safety }\end{array}$} & \multirow[b]{2}{*}{ COR } \\
\hline & & $\mathrm{HSC}$ & & \\
\hline \multirow{2}{*}{ Eurocode EC2 } & \multirow{2}{*}{593} & 370 & 1.60 & 0.974 \\
\hline & & 223 & 1.14 & 0.974 \\
\hline \multirow{2}{*}{$\begin{array}{l}\text { New Zealand } \\
\text { Code }\end{array}$} & \multirow{2}{*}{1402} & 951 & 1.25 & 0.855 \\
\hline & & 451 & 1.12 & 0.882 \\
\hline \multirow{2}{*}{ Canadian Code } & \multirow{2}{*}{1402} & 951 & 1.28 & 0.932 \\
\hline & & 451 & 1.04 & 0.932 \\
\hline \multirow{2}{*}{ ACI Code } & \multirow[t]{2}{*}{1402} & 951 & 1.38 & 0.899 \\
\hline & & 451 & 1.16 & 0.907 \\
\hline
\end{tabular}

Table 3 shows the summary of results showing the Average Margin of Safety $\left(\mathrm{V}_{\text {exp }} / \mathrm{V}_{\text {pre }}\right)_{\text {avg }}$ with COR for NSC and HSC reinforced slender beams including the size effect. It can be also seen from Table 3 that in case of beams with effective depth $\mathrm{d}<300 \mathrm{~mm}$ the COR for Euro code EC2 (2002) Code [7] Eq. 4 is 0.985, which is higher as compared to Canadian Code [5] Eq. 2 (1994), ACI Code [4] Eq. 1 (2008) and New Zealand Code [6] Eq. 3 (1995) which are $0.932,0.90$ and 0.674 respectively. In case of beams with effective depth $\mathrm{d} \geq 300 \mathrm{~mm}$ the COR or Euro code EC2 [7] Eq. 4 is 0.975 , which is higher as compared to Canadian Code [5] Eq. 2 , ACI Code [4] Eq. 1 and New Zealand Code [6] Eq. 3 which are $0.938,0.90$ and 0.899 respectively. It should be noted that the Euro code EC2 [7] Eq. 4 and Canadian code [5] Eq. 2 equations that are identified to have higher values of coefficient of correlation COR use depth factor in their respective expressions, whereas ACI Code [4] Eq. 1 and New Zealand Code [6] Eq. 3 equations do not use depth factor in their relative expressions. Although the COR of Euro code EC2 Code [7] Eq. 4 is higher, however the applicability over the number of beams is limited, due to constraints or the limits in the empirical equation as compared New Zealand Code [6] Eq. 3, Canadian Code [5] Eq. 2 and ACI Code [4] Eq. 1 for which a larger number of test beams were used to assess the predictive accuracy.

\section{Evaluation of Empirical Equations Proposed in the Literature}

Number of empirical equations has been proposed in the literature for predicting the shear capacity of NSC and HSC beams without web reinforcement. Equations 7 to 23 shows empirical equations proposed by Karim et al [11] Eq. 7, Daejoong Kim et al [13] Eq. 8, K.N.Smith [19] Eq. 9 and Eq.10, ASCE-ACI - Committee 426 [1] Eq.11, Crist [21] Eq. 12, Daiz De Cossio et al [22] Eq. 13, Jin-Keun Kim et al [14] Eq. 14, Eq. 15 and Eq. 16, Shuaib et al [17] Eq. 18, Zsutty's [20] Eq. 18 ,Mphonde et al [18] Eq. 19 ,Gastebled et al [10] Eq. 20, Kaiss et al [15] Eq.21, S. Sarkar et al [12] Eq. 22 and Okamura [16] Eq. 23, along with their limits of applicability.

Table 3. Summary of results showing the Average Margin of Safety with coefficient of correlation for NSC and HSC reinforced slender beams including the size effect.

\begin{tabular}{|c|c|c|c|c|}
\hline \multirow{3}{*}{ Code } & \multicolumn{4}{|c|}{ Size Effect } \\
\hline & \multirow{2}{*}{$\begin{array}{c}\text { No. of Beams used for } \\
\text { evaluation }\end{array}$} & $\mathrm{d}<300 \mathrm{~mm}$ & \multirow{2}{*}{$\begin{array}{l}\text { Average Margin of } \\
\text { Safety }\end{array}$} & \multirow{2}{*}{ COR } \\
\hline & & $\mathrm{d} \geq 300 \mathrm{~mm}$ & & \\
\hline \multirow{2}{*}{ Eurocode EC2 } & \multirow{2}{*}{593} & 292 & 1.35 & 0.985 \\
\hline & & 301 & 1.20 & 0.975 \\
\hline \multirow{2}{*}{ New Zealand Code } & \multirow{2}{*}{1402} & 1046 & 1.19 & 0.674 \\
\hline & & 356 & 1.23 & 0.899 \\
\hline \multirow{2}{*}{ Canadian Code } & \multirow{2}{*}{1402} & 1046 & 1.31 & 0.932 \\
\hline & & 356 & 0.90 & 0.938 \\
\hline \multirow{2}{*}{ ACI Code } & \multirow[t]{2}{*}{1402} & 1046 & 1.44 & 0.884 \\
\hline & & 356 & 0.92 & 0.916 \\
\hline
\end{tabular}


It can be seen that effect of $f^{\prime} c$ on the shear capacity of reinforced concrete beams is accommodated through use of $\left(f^{\prime} c\right)^{1 / 2}$ function in the equations proposed by Karim et al [11] Eq. 7, Daejoong Kim et al [13] Eq. 8, K.N.Smith [19] Eq. 9 and Eq.10 , ASCE-ACI - Committee 426 [1] Eq.11, Crist [21] Eq. 12 and Daiz De Cossio et al [22] Eq. 13, through use of $\left(f^{\prime} c\right)^{1 / 3}$ function in the equations proposed by Jin-Keun Kim et al [14] Eq. 14, Eq. 15 and Eq. 16, Shuaib et al [17] Eq. 18, Zsutty's [20] Eq. 18 and Mphonde et al [18] Eq. 19 and through the use of $f^{\prime} c^{0.35}, f^{\prime} c^{0.38}, f^{\prime} c^{0.55}$ and $f^{\prime}$ c functions in the equations proposed by Gastebled et al [10] Eq. 20, Kaiss et al [15] Eq.21, S. Sarkar et al [12] Eq. 22 and Okamura [16] Eq. 23 respectively.

It can be seen that that the issue of size effect is addressed only in equations proposed by Okamura et al [16] Eq. 23, Shuaib et al [17] Eq. 18, Jin-Kuen-Kim et al [14] Eq. 14, Eq. 15 and Eq. 16 and Gastebled et al [10] Eq. 20.

$$
\vartheta_{c}=0.4+\sqrt{f^{\prime}{ }_{c} \rho \frac{d}{a}}\left(10-3 A_{d}\right) \quad \text { For } \frac{a}{d} \geq 2.5, A_{d}=2.5
$$

$$
\begin{aligned}
& \vartheta_{u}=0.2(1-\sqrt{\rho})\left(\frac{d}{a}\right)^{r}\left[\sqrt{f_{c}^{\prime}}\right. \\
& \text { Where } r=\left(\frac{d}{a}\right)^{0.6} \rho^{-.01} \\
& \left.+1020 \rho^{0.9}\left(\frac{d}{a}\right)^{0.6}\right] \\
& r=\text { internal moment arm length } \\
& \text { index } \\
& \vartheta_{c r}=2.6 \sqrt{f_{c}^{\prime}}+3409 \frac{V d \rho}{M} \\
& \vartheta_{c r}=1.74 \sqrt{f_{c}^{\prime}}+4550 \frac{V d \rho}{M} \\
& \vartheta_{c}=(0.8+100 \rho) \frac{\sqrt{f_{c}^{\prime}}}{12} \\
& \vartheta_{c r}=2.27 \sqrt{f_{c}^{\prime}}+2905 \frac{V d \rho}{M} \\
& \leq 0.179 \sqrt{f^{\prime}{ }_{\mathrm{c}}} \mathrm{MPa} \\
& +0.07)
\end{aligned}
$$

For $\frac{a}{d} \geq 3, \propto=1$

$\vartheta_{u}=3.5 f_{c}^{\prime 1 / 3} \rho^{3 / 8}\left(0.4+\frac{d}{a}\right) \lambda(d) \quad \frac{a}{d} \geq 3$

Where, $\lambda(d)=\frac{1}{\sqrt{1+0.008 d}}+0.18$

$$
\begin{gathered}
\vartheta_{u}=19.4 f_{c}^{\prime \alpha / 3} \rho^{3 / 8}\left(0.4+\frac{d}{a}\right)\left(\frac{1}{\sqrt{d}} \quad \text { For } \mathrm{d} \geq 250 \mathrm{~mm}(9.84 \mathrm{in})\right. \\
+0.07)
\end{gathered}
$$

For $\frac{a}{d} \geq 3, \propto=1$

$$
\vartheta_{u}=\eta\left[1.8\left(f_{c}^{\prime} \rho \frac{d}{a}\right)^{0.333}\right]
$$

$$
\begin{aligned}
& \text { For } 3 \leq \frac{a}{d} \leq 6 \\
& \quad \begin{array}{l}
\eta \\
=
\end{array} \\
& -0.00265\left[\frac{(d-135.9)^{0.85}}{\left(\frac{a}{d}\right)^{0.63}}\right] \\
& \text { For } \frac{a}{d} \leq 3
\end{aligned}
$$




$$
\begin{array}{ll}
\vartheta_{u}=2.3\left(f^{\prime}{ }_{c} \rho \frac{d}{a}\right)^{0.333} & \frac{\mathrm{a}}{\mathrm{d}} \geq 2.5 \\
\vartheta_{u}=0.366^{3} \sqrt{f^{\prime}}+0.49 & \frac{a}{d}=3.5 \\
\vartheta_{c} & \text { For } \frac{a}{d} \geq 2 \\
=0.15\left(\frac{37.41}{\sqrt{d}}\right)\left(\frac{3 d}{a_{s}}\right)^{1 / 3}\left(100 \rho_{s}\right)^{1 / 6}(1 & \text { For } \frac{a}{d}>2, \\
\left.-\sqrt{\rho_{s}}\right)^{2 / 3} f_{c}^{\prime}{ }_{c}^{0.35} & 40<f_{c}^{\prime}< \\
\vartheta_{c r}=1.8\left(f_{c}^{\prime} \rho \frac{V_{u} d}{M_{u}}\right)^{0.38} & \\
\vartheta_{n}=3.05\left(f_{c}^{\prime} \rho \frac{d}{a}\right)^{0.55} & \\
\vartheta_{c}=0.20 \frac{\rho^{1 / 3}}{d^{1 / 4}} f_{c}^{\prime}\left[0.75+\frac{1.40}{a / d}\right] &
\end{array}
$$

Table 4. Summary of results for the Average Margin of Safety of empirical equations proposed in literature for predicting the shear capacity of concrete in normal and high beams.

\begin{tabular}{|c|c|c|}
\hline $\begin{array}{c}\text { Authors of the proposed empirical equations, published in } \\
\text { the literature }\end{array}$ & No. of Beams used for Evaluation & $\begin{array}{c}* * \text { Average Margin of } \\
\text { Safety }\left(\mathbf{V}_{\text {exp }} / \mathbf{V}_{\text {pre }} \mathbf{a v g}_{\text {avg }}\right.\end{array}$ \\
\hline Okamura et al & 1402 & 2.677 \\
\hline Shuaib H et al & 1401 & 1.470 \\
\hline Kaiss F. Sarsam et al & 1402 & 1.460 \\
\hline K.N.Smith et al (B) & 1402 & 1.317 \\
\hline Jin-Keun Kim et al (A) & 897 & 1.306 \\
\hline Gastebled et al & 1402 & 1.194 \\
\hline S. Sarkar et al & 1402 & 1.180 \\
\hline Crist & 1402 & 1.117 \\
\hline Daizet al & 1402 & 1.107 \\
\hline Jin-Keun Kim et al(C) & 897 & 1.106 \\
\hline Zsutty & 1402 & 1.050 \\
\hline Jin-Keun Kim et al(B) & 897 & 1.044 \\
\hline ASCE-ACI Committee 426 & 1402 & 1.004 \\
\hline K.N.Smith et al (A) & 1402 & 0.973 \\
\hline Karim et al & 1402 & 0.921 \\
\hline Daejoong Kim et al & 1402 & 0.746 \\
\hline Mphonde et al & 19 & 0.696 \\
\hline
\end{tabular}

** listed in the order of descending order of Average Margin of Safety

Table 4 shows the summary of results in terms of the comparison of the average Margin of Safety's $\left(\mathrm{V}_{\text {exp }} / \mathrm{V}_{\text {pre }}\right)_{\text {avg }}$ of different proposed equations for predicting the shear capacity of reinforced concrete slender beams $(\mathrm{a} / \mathrm{d}>2.5)$. From Table 4, it can be seen that the average Margin of Safety's $\left(\mathrm{V}_{\text {exp }} / \mathrm{V}_{\text {pre }}\right)_{\text {avg }}$ for the empirical equation proposed by Mphonde et al [18] Eq. 19 is 0.67 which is the least among all the empirical equations, with its applicability on only 19 test beams due to its limits. It can be also seen from Table 4 that although the empirical equations proposed by Jin-Keun
Kim et al [14] Eq. 14, Eq. 15 and Eq. 16, have relatively low values of the average Margin of Safety's $\left(\mathrm{V}_{\text {exp }} / \mathrm{V}_{\text {pre }}\right)_{\text {avg }}$ as compared to other proposed empirical equations but its applicability is limited to only 897 test beams as compared to 1402 test beams used for other proposed empirical equations. Therefore in the further evaluation, the empirical equations proposed by Mphonde et al [18] and Jin-Keun Kim et al [14] are not considered.

Table 5 shows the summary of results for the Average Margin of Safety $\left(\mathrm{V}_{\mathrm{exp}} / \mathrm{V}_{\text {pre }}\right)_{\text {avg }}$ and the size effect with 
respective Coefficient of correlation (COR), using the empirical equations of empirical equations proposed in literature for both normal strength concrete (NSC) and high strength reinforced concrete (NSC) slender beams.In case of NSC reinforced slender beams, the equations proposed by Gastebled et al [10] Eq. 20, Shuaib et al [17] Eq. 18 and Kaiss et al [15] Eq.21, have higher values of coefficient of correlation (COR) which are 0.959 , and 0.938 respectively as compared to other proposed equations (Table 5).

In case of HSC reinforced concrete slender beams, the empirical equations proposed by Shuaib et al [17] Eq. 18, Gastebled et al [10] Eq. 20 and Daejoong Kim et al [13] Eq. 8 have higher values of coefficient of correlation (COR) which are $0.967,0.950$ and 0.948 respectively as compared to other proposed equations (Table 5).

Table 5. Summary of results for the Average Margin of Safety and the size effect with respective Coefficient of correlation (COR), using the empirical equations of empirical equations proposed in literature for both normal and high strength reinforced concrete slender beams.

\begin{tabular}{|c|c|c|c|c|}
\hline \multirow{3}{*}{ Author } & \multicolumn{4}{|c|}{ Strength of concrete } \\
\hline & \multirow{2}{*}{ No. of Beams used for Evaluation } & (NSC) & \multirow{2}{*}{ Average Margin of Safety } & \multirow{2}{*}{$\mathrm{COR}$} \\
\hline & & (HSC) & & \\
\hline \multirow{2}{*}{ Gastebled, May } & \multirow{2}{*}{1402} & 951 & 1.24 & 0.959 \\
\hline & & 451 & 1.08 & 0.950 \\
\hline \multirow{2}{*}{ Shuaib et al } & \multirow{2}{*}{1401} & 950 & 1.51 & 0.938 \\
\hline & & 451 & 1.37 & 0.967 \\
\hline \multirow{2}{*}{ Kaiss et al } & \multirow{2}{*}{1402} & 951 & 1.52 & 0.938 \\
\hline & & 451 & 1.33 & 0.942 \\
\hline \multirow{2}{*}{ Daejoong Kim et al } & \multirow{2}{*}{1402} & 951 & 0.74 & 0.936 \\
\hline & & 451 & 0.76 & 0.948 \\
\hline \multirow{2}{*}{ Sarkar et al } & \multirow{2}{*}{1402} & 951 & 1.27 & 0.947 \\
\hline & & 451 & 0.97 & 0.938 \\
\hline \multirow{2}{*}{ Zsutty’s } & \multirow{2}{*}{1402} & 951 & 1.08 & 0.933 \\
\hline & & 451 & 0.98 & 0.941 \\
\hline \multirow{2}{*}{ ASCE-ACI -426 } & \multirow{2}{*}{1402} & 951 & 1.05 & 0.930 \\
\hline & & 451 & 0.9 & 0.929 \\
\hline \multirow{2}{*}{ Karim et al } & \multirow{2}{*}{1402} & 951 & 0.96 & 0.930 \\
\hline & & 451 & 0.85 & 0.943 \\
\hline \multirow{2}{*}{ K.N.Smith et al(B) } & \multirow{2}{*}{1402} & 951 & 1.38 & 0.906 \\
\hline & & 451 & 1.18 & 0.913 \\
\hline \multirow{2}{*}{ K.N.Smith et al(A) } & \multirow{2}{*}{1402} & 951 & 1.025 & 0.899 \\
\hline & & 451 & 0.86 & 0.907 \\
\hline \multirow{2}{*}{ Crist } & \multirow{2}{*}{1402} & 951 & 1.17 & 0.899 \\
\hline & & 451 & 0.98 & 0.907 \\
\hline \multirow{2}{*}{ Daiz De Cossio, Seiss } & \multirow{2}{*}{1402} & 951 & 1.16 & 0.904 \\
\hline & & 451 & 0.99 & 0.911 \\
\hline \multirow{2}{*}{ Okamura et al } & \multirow{2}{*}{1402} & 951 & 3.15 & 0.966 \\
\hline & & 451 & 1.68 & 0.919 \\
\hline
\end{tabular}

In Table 5, generally the equations which uses cubic power or power lesser than square root on $f^{\prime} \mathrm{c}$ to reflect the effect of the concrete compressive strength $f^{\prime} \mathrm{c}$ on the shear capacity of reinforced concrete slender beams have higher values of COR as compared to the equations which use power equal to or higher than square on $f^{\prime} \mathrm{c}$ to reflect the effect of the concrete compressive strength $f^{\prime} \mathrm{c}$ on the shear capacity of reinforced concrete beams. Exception in the proposed equation of Daejoong Kim et al [13] Eq. 8 which uses square power on $f^{\prime} \mathrm{c}$ and has a COR value of 0.948.

Table 6 also shows the summary of results Average Margin of Safety $\left(\mathrm{V}_{\text {exp }} / \mathrm{V}_{\text {pre }}\right)_{\text {avg }}$ with respective COR's for reinforced concrete slender beams with effective depth $\mathrm{d}<300 \mathrm{~mm}$ and with effective depth $\mathrm{d} \geq 300 \mathrm{~mm}$. For reinforced concrete slender beams with effective depth $\mathrm{d}<300 \mathrm{~mm}$, empirical equations proposed by Zsutty's [20] Eq. 18, Kaiss et al [15] Eq.21, Karim et al [11] Eq. 7 and Shuaib et al [17] Eq. 18 have higher values of COR's, which are 0.901, 0.896 and 0.896 respectively as compared to other proposed equations (Table 6). For 355 reinforced concrete slender beams with an effective depth $\mathrm{d} \geq$ $300 \mathrm{~mm}$, empirical equation proposed by Shuaib et al (1986) and Gastebled et al have the higher values of COR's, which are 0.967 and 0.965 respectively as compared to other proposed equations (Table 6). It is important to note that empirical equations proposed by Shuaib et al [17] Eq. 18 and Gastebled et al [10] Eq. 20 use the size effect and depth factor variable in their expressions to reflect the shear capacity of reinforced concrete slender beams. 
Table 6. Summary of results for the Average Margin of Safety and the size effect with respective Coefficient of correlation (COR), using the empirical equations of empirical equations proposed in literature for both normal and high strength reinforced concrete slender beams.

\begin{tabular}{|c|c|c|c|c|}
\hline \multirow{3}{*}{ Author } & \multicolumn{4}{|c|}{ Size Effect } \\
\hline & \multirow{2}{*}{$\begin{array}{l}\text { No. of Beams used for } \\
\text { Evaluation }\end{array}$} & $\mathrm{d}<300 \mathrm{~mm}$ & \multirow{2}{*}{$\begin{array}{l}\text { Average Margin of Safety } \\
\qquad\left(\frac{v_{\text {exp }}}{v_{\text {pre }}}\right)\end{array}$} & \multirow[b]{2}{*}{$\mathrm{COR}$} \\
\hline & & $\mathrm{d} \geq 300 \mathrm{~mm}$ & & \\
\hline \multirow{2}{*}{ Gastebled, May } & \multirow{2}{*}{1402} & 1046 & 1.21 & 0.869 \\
\hline & & 356 & 1.15 & 0.965 \\
\hline \multirow{2}{*}{ Shuaib et al } & \multirow{2}{*}{1401} & 1046 & 1.51 & 0.896 \\
\hline & & 355 & 1.35 & 0.967 \\
\hline \multirow{2}{*}{ Kaiss et al } & \multirow{2}{*}{1402} & 1046 & 1.55 & 0.896 \\
\hline & & 356 & 1.17 & 0.948 \\
\hline \multirow{2}{*}{ Daejoong Kim et al } & \multirow{2}{*}{1402} & 1046 & 0.77 & 0.868 \\
\hline & & 356 & 0.65 & 0.949 \\
\hline \multirow{2}{*}{ Sarkar et al } & \multirow{2}{*}{1402} & 1046 & 1.24 & 0.857 \\
\hline & & 356 & 0.98 & 0.948 \\
\hline \multirow{2}{*}{ Zsutty's } & \multirow{2}{*}{1402} & 1046 & 1.12 & 0.901 \\
\hline & & 356 & 0.84 & 0.863 \\
\hline \multirow{2}{*}{ ASCE-ACI -426} & \multirow{2}{*}{1402} & 1046 & 1.03 & 0.760 \\
\hline & & 356 & 0.91 & 0.951 \\
\hline \multirow{2}{*}{ Karim et al } & \multirow{2}{*}{1402} & 1046 & 0.98 & 0.896 \\
\hline & & 356 & 0.74 & 0.947 \\
\hline \multirow{2}{*}{ K.N.Smith et al(B) } & \multirow{2}{*}{1402} & 1046 & 1.43 & 0.892 \\
\hline & & 356 & 0.95 & 0.922 \\
\hline \multirow{2}{*}{ K.N.Smith et al(A) } & \multirow{2}{*}{1402} & 1046 & 1.07 & 0.884 \\
\hline & & 356 & 0.68 & 0.916 \\
\hline \multirow{2}{*}{ Crist } & \multirow{2}{*}{1402} & 1046 & 1.23 & 0.884 \\
\hline & & 356 & 0.78 & 0.916 \\
\hline \multirow{2}{*}{ Daiz De Cossio, Seiss } & \multirow{2}{*}{1402} & 1046 & 1.21 & 0.890 \\
\hline & & 356 & 0.79 & 0.890 \\
\hline \multirow{2}{*}{ Okamura et al } & \multirow{2}{*}{1402} & 1046 & 2.83 & 0.790 \\
\hline & & 356 & 2.22 & 0.879 \\
\hline
\end{tabular}

\section{Proposed Empirical Equation}

On the basis of shear data base of the experimental test results [3], an empirical equation is developed for predicting the shear capacity of reinforced concrete beams having shear span to depth ratio $\mathrm{a} / \mathrm{d} \geq 2.5$.

For $\mathrm{d}<300 \mathrm{~mm}$ and $\frac{a}{d} \geq 2.5$

$$
\vartheta=0.35\left(\frac{a}{d} f^{\prime} c\right)^{0.33} \rho^{0.1}
$$

For $\mathrm{d} \geq 300 \mathrm{~mm}$ and $\mathrm{a} / \mathrm{d} \geq 2.5$

$$
\vartheta=\xi 0.35\left(\frac{a}{d} f^{\prime} c\right)^{0.33} \rho^{0.1}
$$

where

$$
\xi=\frac{17.32}{\sqrt{d}}
$$

The proposed empirical equations (Eq. 24 and Eq. 25), contains basic parameters i.e. concrete compressive strength $f^{\prime} \mathrm{c}$, shear span to depth ratio a/d and ratio of longitudinal reinforcement $\rho$. In addition to these basic parameters, proposed equation also uses depth factor $\xi$ to account the effect of size effect on the shear capacity of reinforced concrete beams without web reinforcement. In order to assess the predictive accuracy of proposed empirical equations (Eq. 24 and Eq. 25), test results of 1085 reinforced concrete beams without web reinforcement from ACCESS shear database (Rafeeqi et al 2011) were used. The COR for Eq. 24 comes out to be 0.869 . For the predictive accuracy of Eq. 25 test results of 393 reinforced concrete beams without web reinforcement from ACCESS shear database [3] were used. The COR for Eq. 25 comes out to be 0.953. Although the COR of the proposed empirical equation is less as compared to equations of Shuaib et al [17] Eq. 18 and Gastebled et al [10] Eq. 20, the applicability of the proposed equation is over a larger number of beams (393) as opposed to 355 beams for equations proposed by Shuaib et al [17] Eq. 18 and Gastebled et al [10] Eq. 20.

\section{Summary and Conclusions}


From the evaluation study of design equations used in different codes of practice to predict the shear capacity of reinforced concrete slender beams, the following conclusions can be drawn;

1) The predictions of CEB-FIP Model Code and Espanish EHE-99 are much more conservative as compared to ACI Code, Euro code EC2, New Zealand Code and Canadian Code.

2) For NSC and HSC beams, the predictive accuracy of Euro code EC2, ACI Code, Canadian Code and New Zealand Code is comparable.

3) The $\left(f^{\prime} c\right)^{1 / 2}$ function used in the ACI Code, Canadian Code and New Zealand Code seems to be inadequate to reflect the effect of the $f^{\prime} \mathrm{c}$ on the shear capacity for higher strength concrete.

4) The $\left(f^{\prime} \mathrm{c}\right)^{1 / 3}$ function used in Euro code EC2 seems to be better in reflecting the effect of the $f^{\prime} \mathrm{c}$ on the shear capacity.

5) The issue of size effect is addressed in equations of Euro code EC2 and Canadian Code. The equations used by, Euro code EC2 and Canadian Code have higher values of coefficient of correlation (COR) for beams with effective depth $\mathrm{d} \geq 300 \mathrm{~mm}$ as compared to ACI Code and New Zealand Code equations which do not have a depth factor in their respective expressions.

From the evaluation study of proposed empirical equations published in the literature following conclusions can be drawn;

1) the shear capacity of reinforced concrete slender beams, considering all beams (NSC as well as HSC beams) with $\mathrm{d}<300 \mathrm{~mm}$ as well as with $\mathrm{d}<300$ $\mathrm{mm}$, overall the empirical equation proposed by Shuaib et al provides the highest COR and thus is considered to be the superior to the other equations.

2) An empirical equation is developed that is applicable to test data of 393 beams. For beams with effective depth $\mathrm{d}<300 \mathrm{~mm}$, the COR for the proposed equation is 0.869 and for beams having effective depth $\mathrm{d} \geq 300 \mathrm{~mm}$, the COR for the proposed equation is 0.953 .

\section{REFERENCES}

[1] Joint ACI-ASCE Committee 445 Report, Recent Approaches to Shear Design of Structural Concrete, ACI 445R-99.

[2] Concrete Tension and Size Effects - Utilisation of concrete tension in structural concrete design and relevance of size effect - Contributions from CEB Task Gr. 2.7 (1997; ISBN 978-2-88394-036-9; 258 pages).

[3] S.F.A Rafeeqi, Shuaib H Ahmad \& ShamsoonFareed, "Shear strength of reinforced concrete beams - relational data base", submitted for possible publication, Arabian journal of Science \& Engineering, December, 2012.
[4] ACI Committee 318, "Building Code Requirement for Reinforced Concrete (ACI 318-08)," American Concrete Institute, Detroit,1983.

[5] Design of concrete structures with explanatory notes. CSA, Ontario CSA committee A23-3,1994

[6] Code of Practice for the Design of Concrete Structures (NZS 3101 )," NZS Wellington, 1995.

[7] European Committee for Standardization, Eurocode 2:Design of Concrete Structures - Part 1-1: General rules and rules for Buildings, Revised Final Draft, April 2002, 226 pp.

[8] Comisionpermanentedelhormingon (1999), Instruccion de HormigonEstructural EHE, Ministerio de Fomento, 476 pp.

[9] CEB/FIP (1990)., " CodigoModelo CEB-FIP 1990 parahormigonestructural", (E-4). Traduccion Espanola de GEHO., Colegio de Ingenieros de Caminos , C. y P. /GEHO/ ATEP, 1995.

[10] Gestebled, O.J., May, I. M., Fracture Mechanics Model Applied to Shear Failure of Reinforced Concrete Beams without Stiirups, ACI Structural Journal, Vol. 98, No.2, Mar-April 2001, pp.184-190.

[11] Karim S.R., Fente.J.,Frabizzio.M., (2000) “ New Shear Strength Prediction For Concrete Using Statistical and Interpolation function Techniques" 8th ASCE Specialty Conference on Probabilistic Mechanics and Structural Reliability. pp 1-6.

[12] S. Sarkar, O. Adwan and B. Bose, Shear Stress Contributions and Failure Mechanisms of High Strength Reinforced Concrete Beams, Materials and structures, Vol.32, March1999, pp 112-116.

[13] Daejoong Kim, Woo Kim and Richard N. White, Arch Action in Reinforced Concrete Beams-A Rational Prediction of Shear Strength, ACI Structural Journal, Vol. 96, No.4, Jul-Aug 1999, pp.586-557.

[14] Jin-Keun Kim and Yon-Dong Park, Prediction of Shear Strength of Reinforced Concrete Beams without Web Reinforcement, ACI Materials Journal, V. 93, No. 3, May-June 1996, pp. 213-222.

[15] Kaiss F. Sarasam and Janan M. S. Al-Musawi, Shear Design of High- and Normal Strength Concrete Beams with Web Reinforcement, ACI Structural Journal, Vol.89, No.6 Nov-Dec 1992, pp.658-664.

[16] Okamura, H., and Higai, T., 1980, "Proposed Design Equation for Shear Strength of R.C. Beams without Web Reinforcement,"Proceedings, Japan Society of Civil Engineering, 300, pp. 131-141.

[17] Shuaib H. Ahmad, A.R. Khaloo, and A. Poveda, Shear Capacity of Reinforced High- Strength Concrete Beams, ACI Journal, Mar-Apr 1986, pp.297-305.

[18] Andrew G. Mphonde and Gregory C. Frantz, Shear Tests of High- and Low- Strength Concrete Beams Without Stirrups, ACI Journal, Jul-Aug 1984, pp 350-357.

[19] K.N. Smith, and A.S. Vantsiotis, Deep Beam Test Results Compared with Present Building Code Models, ACI Journal, Jul-Aug 1982, pp.280-287.

[20] Theodore Zsutty, Shear Strength Prediction for Separate 
Categories of Simple Beam Tests, ACI Journal, Feb 1971, pp.138-143.

[21] Crist Robert A., " Shear Behviour of Deep, Reinforced concrete Beams," Proceedings , Rilem Symposium on the Effects of Repeated Loading of Materials and Structural Elements (Mexico city, 1966), Instituto de Ingenieria, Mexico, D.F., 1967 , V. 4, 31 pp.
[22] Roger Diaz De Cossio and Chester P. Siess, Behaviour and Strength in Shear of Beams and Frames Without Web Reinforcement, Journal of American Concrete Institute Feb. 1960, pp.695-735. 